\title{
Cultural Contacts between Ethiopia and Syria: The Nine Saints of the Ethiopian Tradition and Their Possible Syrian Background
}

\author{
Blessen George Babu
}

While studying the early and mediaeval histories of Ethiopia, one cannot easily neglect its cultural contacts involving the rest of Christendom, which indisputably eventuated Ethiopia to emerge as one of the ancient Christian domains of Africa. Correspondingly, the spread of Christianity throughout Ethiopia during the Aksumite era, as recounted in a florilegium of Ethiopian hagiographies, is traditionally ascribed to the contributions of the 'Nine Saints': ${ }^{1}$ a group of foreigners, presumably monks, "several of royal or near royal Roman birth," who, by a certain number of scholars in the West ${ }^{3}$ were assumed and classified

1 The following are the names of the Nine Saints arranged in alphabetical order along with their date of commemoration (although the corresponding hagiographies might carry slight variations), based on the English translation of the Ethiopian Synaxarium. Ernest A. Wallis Budge, The Book of the Saints of the Ethiopian Church. Vol. 1/2 (Hildesheim: Georg Olms Verlag, 1976), 116-118, 155, 198, 299-300, 505; Ernest A. Wallis Budge, The Book of the Saints of the Ethiopian Church. Vol. 3/4 (Hildesheim: Georg Olms Verlag, 1976), 688, 944, 1009-1110. Afșe (29 Gənbot = ca. 6 June), Alef (11 Mäggabit = ca. 20 March), Gärima or Yəsḥaq (17 Säne = ca. 24 June), Guba (29 Gənbot = ca. 6 June), Liqanos (28 Hədar $=$ ca. 8 December $)$, Pänțälewon (6 Ṭəqəmt = ca. 17 October), Șəḥma ( 16 Ṭərr = ca. 25 January $)$, Yəm’ata $(28$ Țəqəmt = ca. 7 November $)$, Zämika'el Arägawi or Arägawi (14 Ṭəqəmt = ca. 25 October).

Moreover, the number 'nine' need not be necessarily taken for granted as accurate, since the variations in the names might also indicate the possibility that they might be more than nine. For instance, we sometimes also find a tenth name, 'Oṣ (4 Tahśaś = ca. 13 December) affixed to this list, but interchangeably used also for Guba and Afșe. Stuart C. Munro-Hay, "Saintly Shadows," in Afrikas Horn: Akten der Ersten Internationalen Littmann-Konferenz, 2. bis 5. Mai 2002 in München, ed. Walter Raunig and Steffen Wenig (Wiesbaden: Harrassowitz, 2005), 138; Antonella Brita, "Nine Saints," in EAe 3 (2007): 1188.

2 Munro-Hay, "Saintly Shadows," 137.

3 Although the label 'Western' in general is grandiloquent and terms like 'West' (or 'Occident') may sound vague just as how its antipodal counterpart 'East' (or 'Orient') does, the terminological distinction 'West' or 'Western' as applied in this paper refers explicitly to the contributions of scholars from Europe who were involved in the field of Ethiopian studies. 
in general to be 'Syrian' monks and were believed to have sown Christianity and monastic life in the kingdom of Aksum during a time period collectively addressed as the 'second evangelization' 4 in the history of Ethiopian Christianity, i.e. the end of the fifth and the beginning of the sixth century. ${ }^{5}$

What little available knowledge we receive about these foreign monks is on a large extent based on their Ethiopic hagiographies known as gädlat ${ }^{6}$ a literary form that originated most probably by the end of the 14th century or the beginning of the $15^{\text {th }}$ century, ${ }^{7}$ where the Gə'əz hagiographers, according to Munro Hay, "fill in quite lavishly one section of the Aksumite 'dark age', in the late fifth and early sixth centuries, with the rich tapestry of the lives of the so-called Nine Saints"8 such as the Gädlä Pänțälewon (14th century), ${ }^{9}$ the Gädlä Gärima (15th century), ${ }^{10}$ the Gädlä Zämika'el Arägawi (16th century), ${ }^{11}$ and the Gädlä Afșe ${ }^{12}$ most of these works are pseudepigraphs

$4 \quad$ The first feat of evangelization was accomplished by Fremnatos (Frumentius), who was later appointed as the first bishop of Aksum and is popularly known by his Ethiopian appellation, Abba Sälama ('Father of Peace') and Käśate Bərhan ('Revealer of Light'). For further reading on Frumentius, see: Budge, The Book of the Saints. Vol. 3/4, 1164-1165.

Sergew Hable Sellassie, Ancient and Medieval Ethiopian History to 1270 (Addis Ababa: United Printers, 1972), 115-121; Arthur Vööbus, History of Asceticism in the Syrian Orient: A Contribution to the History of Culture in the Near East. Vol. 3 (Louvain: Secrétariat du Corpus sco, 1958), 274-278; Carlo Conti Rossini, Storia d'Etiopia (Bergamo: Istituto Italiano d'Arte Grafiche, 1928), 162-163; Brita, "Nine Saints"; Munro-Hay, "Saintly Shadows"; Albert Kammerer, Essai sur l'histoire antique d'Abyssinie. Le royaume d'Aksum et ses voisins d'Arabie et de Meroe (Paris: Geuthner, 1926), 103-104.

6 Gädlat (singular: $g a ̈ d l)$, literally meaning 'contending,' 'spiritual combat,' but comprises also a meaning of 'Life', 'Acts', 'Biography (of a holy person).' Cf. Wolf Leslau, Comparative Dictionary of Ge'ez (Classical Ethiopic): Ge'ez-English, English-Ge'ez, with an Index of the Semitic Roots (Wiesbaden: Harrassowitz, 1987), 182.

For a brief reading on the Ethiopian hagiographies, see: Antonella Brita, "Hagiography and Monasticism in the Ethiopian Church," in Ethiopia: History, Culture and Challenges, ed. Siegbert Uhlig et al. (Münster: Lit, 2017), 230-233.

8 Munro-Hay, "Saintly Shadows," 137.

9 Carlo Conti Rossini, Vitae Sanctorum Antiquiorum. Vol. 1: Acta Yāred et Panțalewon (Leuven: Durbecq, 1955).

10 Carlo Conti Rossini, "L'Omilia di Yohannes, Vescovo d'Aksum, in Onore di Garimâ," in Actes du XIe Congrès International des Orientalistes. Paris. 1897. Vol. 4 (Paris: Impr. nationale, 1898), 139-177.

11 Ignazio Guidi, "Il 'Gadla Aragâwî," in Atti della R. Accademia dei Lincei, Classe di Scienze Morali, Storiche e Filologiche. Vol. 2 (Roma:Tipografia della R. Accademia dei Lincei, 1896), 54-96; Marcus Antonius van den Oudenrijn, La vie de saint Za Mīkāêel 'Aragāwī (Fribourg: Imprimere St.-Paul, 1939).

12 This is the version seen only by Conti Rossini in the year 1937 and is not available anymore. Carlo Conti Rossini, "La Leggenda di Abbā Afșē in Etiopia," in Mélanges Syriens Offerts à Monsieur René Dussaud. Vol. 1 (Paris: Librairie orientaliste Paul Geuthner, 1939), 151-156. 
where the names of the authors are either false or purportedly accredited to popular historical figures of the past. ${ }^{13}$

Furthermore, it is necessary also to understand here the diachronic incongruity involved in the historical settings of this tradition. One can imagine this as represented by a mathematical 'Venn diagram of three sets,' with the tradition itself at the intersection and the outer three circles representing respectively: the world of the events as portrayed in their textual sources (that would rather point to the Late Antiquities), the time of composition of the accounts in their available written formats (which would apparently be not earlier than the 14th century) and finally, the recent suppositions and the scholarly developments that occurred in the field of Ethiopian studies related to the tradition of Nine Saints.

Moreover, the subject upholds a protuberant place in Ethiopian studies due to the convoluted scholarly discussions, since the earlier propositions of some prominent scholars like Ignazio Guidi, Carlo Conti Rossini, and of few church historians like Arthur Vööbus, overtly generalizing the saints as 'Syrian' missionaries based on some rather weak philological arguments, were exposed in the recent fields of scholarship as unconvincing and untenable. ${ }^{14}$ However, the presumed Syrian identity of these saints that were earlier postulated by these

Meanwhile, the remaining hagiography texts that are attributed to the names of these saints such as the texts of Gädlä Afșe (the version that is accessible at present), "Gädlä Guba (recently found and closely linked to the Gädlä Afșe), Gädlä Alef, Gädlä Liqanos, Gädlä Ṣ̆ḥma, and Gädlä Yəm’ata [...] belong all to a later period (probably between the 19th and 2oth centuries)." Brita, "Nine Saints," 1189. Cf. also Hagos Abrha, "Philological Analysis of the Manuscripts of Gädlä Yəm‘ata," Ityopis 1 (2011): 61-75.

13 For example, 'Yared' as the author of Gädlä Arägawi, Gädlä Șəḥma and Gädlä Yam’ata; 'Athanasius' for Gädlä Afșe and Gädlä Guba; Yohannəs, the Bishop of Aksum, for Gädlä Gärima; and Rətu'a Haymanot or in some occasions Yəsḥaq for Gädlä Pänțälewon. Brita, "Nine Saints," 1189. We also get to know of them, especially of Zämika’el Arägawi, Gärima, and Pänțälewon, from the brief accounts of their biography mentioned in the Ethiopian Synaxarium. For reference to the English translation of the Synaxarium see fn. 1. However, the scant notes about the Nine Saints in the Synaxarium according to Munro-Hay, were rather added to 'Ethiopianise' the work at some time after the original Gə`əz translation and was apparently prepared by a certain Abba Səm'on in the fourteenth century. MunroHay, "Saintly Shadows," 140. For a brief understanding on the life and acts of the Nine Saints as recounted in their hagiographic texts, see: Belaynesh Michael, S. Chojnacki, and Richard Pankhurst, The Dictionary of Ethiopian Biography: From Early Times to the End of the Zagwé Dynasty c. 1270 A.D. Vol. 1 (Addis Ababa: Institute of Ethiopian Studies, 1975).

14 Hans Jakob Polotsky, "Aramaic, Syriac, and Ge'ez," Journal of Semitic Studies 9 (1964): 1-10; Paolo Marrassini, "Una Chiesa Africana. L'Etiopia fra Antiochia e Alessandria," in XXVIII Corso di Cultura sull'Arte Ravennate e Bizantina (Ravenna: Edizioni del Girasole, 1981), 193- 
scholars in the West received also its acceptance among the Ethiopians who already cherish the tradition of Nine Saints as part of their "cultural memory,"15 awarding the saints some feasible credit towards their liturgical, theological, cultural, and, linguistic developments. ${ }^{16}$

Nevertheless, within the more generic problem of 'Syrian influences on the Aksumite Ethiopia ${ }^{17}$ which is a matter of deliberation among scholars, the appellation of the Nine Saints as Syrian monks cannot be completely overlooked as wrong either, but rather demands a deeper investigation and even when the validation for substantial 'Syrian influence' on Ethiopian Christianity during the Aksumite period looks slim, it may not be totally non-existent. In view of the above, the following paper is an attempt based on the notion of 'cultural memory' to reassess the identification of 'Syrian' associated with this tradition along with their concomitant historical discrepancies by proceeding further from textual and philological pieces of evidence towards the consideration of a few socio-cultural aspects.

203; Paolo Marrassini, "Some Considerations on the Problem of the 'Syriac Influences' on Aksumite Ethiopia," Journal of Ethiopian Studies 23 (1990): 35-46; Paolo Marrassini, "Once Again on the Question of Syriac Influences in the Aksumite Period," in Languages and Cultures of Eastern Christianity: Ethiopian, ed. Alessandro Bausi (Farnham: Ashgate, 2012), 209-219; Paolo Marrassini, "Frustula Nagranitica," Aethiopica 14, no. 1 (2011): 732; Antonella Brita, I racconti tradizionali sulla Seconda Cristianizzazione dell'Etiopia: Il ciclo agiografico dei Novi Santi (Napoli: Università degli studi di Napoli l'Orientale, 2010); Paolo Marrassini, Storia e leggenda dell'Etiopia tardoantica. Le iscrizioni reali aksumite con un'appendice di Rodolfo Fattovich su La civiltà aksumita: aspetti archeologici e una nota editoriale di Alessandro Bausi (Brescia: Paideia, 2014).

15 " [...] a collective concept for all knowledge that directs behaviour and experience in the interactive frame-work of a society and one that obtains through generations in repeated societal practice and initiation." Jan Assmann and John Czaplicka, "Collective Memory and Cultural Identity," New German Critique 65 (1995): 126.

16 Arthur Vööbus in his work History of Asceticism in the Syrian Orient mentions the following as a brief note about the Nine Saints: "In a series of Ethiopian documents, these men are celebrated as the fathers of Christianity in Abyssinia. We hear that they reformed customs, introduced Christian discipline, and successfully fostered religious and ecclesiastical institutions. Further, they gave the Church its liturgy and established monasticism. As information stands, we must conclude that their influence and impact covered the entire field of spiritual life, and that owing to this impetus, the Christian cause took a new turn in the country." Vööbus, History of Asceticism, 276.

17 Witold Witakowski, "Syrian Influences in Ethiopian Culture," in Languages and Cultures of Eastern Christianity: Ethiopia, ed. Alessandro Bausi (Farnham: Ashgate, 2012), 197208. 
The tradition of the Nine Saints has evoked a few substantial debates among the scholars of Ethiopian studies as the subject also to a large degree encompasses the issues regarding the Gə'əz translation of the Bible. The grounds for discussion were apparently paved during the end of the nineteenth century ${ }^{18}$ when the saints were addressed by certain scholars generically as 'Syrian monks' based on their assumptions from a number of Syriac elements supposedly identified in the early manuscripts of their hagiographic accounts, which in addition also augmented the hypotheses on the topic of Syrian influences in Aksumite Ethiopia. ${ }^{19}$

Although scholars like Guidi and Conti Rossini perhaps attempted only to construct an image of the Nine Saints based on the historical settings of the time procuring the benefits of doubt that they could have been Monophysite Syrian monks who reached Ethiopia while fleeing from the Byzantine persecution, ${ }^{20}$ the problem arises when they further assert the notion of a 'Syrian

18 This time period, i.e. the end of the nineteenth century, was also marked by some noteworthy studies within the branch of New Testament textual criticism, like that of Westcott and Hort's edition of the New Testament in Original Greek, that was aimed at presenting exactly the original words of the New Testament in the best possible manner deduced from the extant materials. Cf. Brooke Foss Westcott and Fenton John Anthony Hort, The New Testament in the Original Greek (Cambridge: Macmillan and Co., 1882). Consequently, such scholarly attentions to Bible translations and editions acted as the corresponding catalysts in the field of Ethiopian studies, as in most cases the several suggestions of scholars seem to have emerged out of the their attempts in finding solutions for the problem of the translation of the Gə`əz Bible. Edward Ullendorff, Ethiopia and the Bible (London: Oxford University Press, 1968), 33.

19 "According to this theory, immediately after the council of Chalcedon in 451, Syriac monks fled to Ethiopia from their original country, but also from South Arabia and Egypt, and were instrumental, or even essential, in a deeper rooting of Christianity in Ethiopia, and also in the translation of at least some parts of the New Testament." Marrassini, "Some Considerations," 35 .

20 Conti Rossini, in his extensive work on Ethiopian history, Storia d'Etiopia, suggests and relates the legends of the Nine Saints to similar circumstances when at the time of the Byzantine Emperor Justin I (518-527), numerous non-Chalcedonians of Syria, expelled by him, first sheltered in al-Hīrā, then in Nağrān where they propagated their doctrine and thus giving rise to an obvious chance to assume that these missionaries or ecclesiastics of Syria must have also come to Ethiopia in the same fashion; cf. Conti Rossini, Storia d'Etiopia, 162. Thus, it is possible to convincingly assume that the Nine Saints might have belonged to the mass of Non-Chalcedonian exiles fleeing from the persecution of the Byzantine Empire against their own faith. Also, some of the immediate and later events that ensued from the results of Chalcedon such as the Henotikon, and the subsequent 
identity' to them based on three remote possibilities, namely: the place of origin of the Saints, the personal names of the Saints, and the testimony that involves a Syriac contribution in the translation of the Bible to Ethiopic during the aforesaid time period. ${ }^{21}$ Besides, the affirmative approach of Arthur Vööbus towards the use of Syriac translation techniques in the Ethiopic translation of the Bible, ${ }^{22}$ also calls for our attention in this problem as he further shares the general assumption that the Nine Saints were Syrian monks who translated the four gospels into Gəəəz. ${ }^{23}$ However, almost all of their arguments do not really seem to be substantial or reliable enough to favour the theory, ${ }^{24}$ even when this would leave some gaps to be filled within the question of the translation of the Ethiopic Bible. Paolo Marrassini (1942-2013), in one of his later articles, remarks that

monastic reaction towards it appear to be plausibly validating the above suggestion that they could perhaps be fugitives who reached Ethiopia in search of asylum. Gianfranco Fiaccadori, "Between Arabia and Ethiopia," in Life and Works of Saint Gregentios, Archbishop of Taphar: Introduction, Critical Edition and Translation, ed. Albrecht Berger (Berlin: Walter de Gruyter, 2006), 65. Yet, it would still be a hasty conclusion to exclusively refer the repercussions of Chalcedon as the sole reason behind their migration. This is because their relocation to Ethiopia could also be related to contrasting motives than the above as we see in the Mäșhafä Maśțir (Book of the Mystery) written by Giyorgis of Sägla, a 15th century Ethiopian monk who introduces the Nine Saints as coming to Ethiopia "with their kings, with their princes and with their dignitaries, their priests, with their altars, with their sacred furniture, with their books and with their people," persuasively instigating the thought that they might have probably also had intentions of invading the country with an evangelistic zeal. Yaqob Beyene, ed. and trans., Giyorgis di Saglā: Il Libro del Mistero (Mașhafa Mesțir). Parte Prima (Louvain: Peeters, 199o), 73-74; quoted in Marrassini, "Frustula Nagranitica," 10. Hence, "[...] until now we have no hint whatsoever as to whether it was due to the unhappy and disastrous religious policy of the Byzantine rulers who possessed a proven talent of agitating the inhabitants of the Eastern provinces against the state, or whether it was due to the natural zeal of expanding Monophysitism or to church political considerations, namely, to find new allies in the South at a time when they felt a gathering of the storm clouds." Vööbus, History of Asceticism, 276.

21 Ignazio Guidi, Le Traduzioni degli Evangeli in Arabo e in Etiopico (Roma: Salviucci, 1888), 33-34; Ignazio Guidi, Storia della Letterature Etiopica (Rome: Istituto per l'Oriente, 1932), 13-15; Conti Rossini, Storia d'Etiopia, 155-556, 161-162; Conti Rossini, “La Leggenda Di Abbā Afșē in Etiopia," 151-156; Conti Rossini, "Lomilia Di Yohannes, Vescovo d'Aksum, in Onore Di Garimâ," 140, 174-175.

Arthur Vööbus, Early Versions of the New Testament: Manuscript Studies (Stockholm: Estonian Theological Society in Exile, 1954), 253.

23 Vööbus, History of Asceticism, 275-277.

24 For further reading on the discussions against the 'Syrian' background of the Nine Saints based on the textual and linguistic evidences, see fn. 14 . 
[...] the Syriac origin of the Nine Saints can still be considered to be nothing but a modern story, created accidentally in the West, after a series of mistakes and misunderstandings of some of the most authoritative scholars of that time, and accepted in Ethiopia for (unusual) psychological submissiveness. ${ }^{25}$

Meanwhile, apart from the linguistic or textual propositions, there seems to also exist another typology of evidence based on a comparison between the ascetic practices in Ethiopia and Syria, which, although they might only be a speculative analysis of some hypothetical demonstrations, still draws our attention towards understanding the problem, especially while dealing the topic in line with the notion of cultural memory.

\section{Syrianness of the Nine Saints as a Phenomenon of Cultural Memory}

Jan Assmann, the renowned cultural scientist and religious scholar of our contemporary era, elucidates the theories of collective memory put forward by Maurice Halbwachs and Aby Warburg ${ }^{26}$ and subsequently coins the term 'cultural memory' by labelling the different carriers of communication such as oral traditions, texts, monuments and rituals collectively as "figures of memory."27 The meaning of the term 'cultural memory', as it is applied in this paper with regard to the tradition of the Nine Saints, therefore embraces the multiple elements of cultural remembrances and is based on the explanation given by Jan Assmann, which is as follows:

[...] cultural memory, [is] a collective concept for all knowledge that directs behaviour and experience in the interactive framework of a society and one that obtains through generations in repeated societal practice and initiation. [...] The concept of cultural memory comprises that body of reusable texts, images, and rituals specific to each society in each

25 Marrassini, "Frustula Nagranitica," 14.

26 Maurice Halbwachs, On Collective Memory, ed. and tr. Lewis A. Coser (Chicago: University of Chicago Press, 1992); Roland Kany, Mnemosyne als Programm: Geschichte, Erinnerung und die Andacht zum Unbedeutenden im Werk von Usener, Warburg und Benjamin (Tübingen: Niemeyer, 1987).

27 Assmann and Czaplicka, "Collective Memory and Cultural Identity," 129. 
epoch, whose "cultivation" serves to stabilize and convey that society's self-image. Upon such collective knowledge, for the most part (but not exclusively) of the past, each group bases its awareness of unity and particularity. ${ }^{28}$

Accordingly, the hagiographic texts, monastic practices, archaeological sites, iconography and religious paintings and any other related 'figures of memory' concerning the tradition of the Nine Saints can be applicably analysed to review the notion of 'Syrianness' involved within the subject matter. In this paper, we deal particularly with the hagiographic genre and the monastic units related to the saints as 'figures of memory' evolving within the different sociopolitical and religious contexts of Ethiopia that may perhaps lead us to some possible Syrian elements. ${ }^{29}$

\subsection{Ethiopian Hagiographies as Socio-politico-religious Figures of Memory}

The hagiographic genre of gädlat is a part of the very old and time-hallowed traditions of Ethiopia and was among the "first works to be translated from Greek into Gəəəz during the Aksumite period, soon after the Christianization of the country." ${ }^{30}$ However, a serious problem arises when one attempts to distinguish between Ethiopian hagiography and history since the work might be far from being a text that could provide precise historical data. As Steven Kaplan in his article Hagiographies and the History of Medieval Ethiopia points out:

28 Ibid., 126, 132.

29 By the appellation 'Syrian,' I here intend to borrow the approach of Witold Witakowski who in his article Syrian influences in Ethiopia attempts to distinguish between the terms 'Syrian' and 'Syriac' influences. While the latter has largely to do with the realm of linguistics and oftentimes corroborates to direct contacts and influences, the former one on the contrary, although it might occasionally stand witness to direct contacts, would more often testify indirect influences that sketch a possible scope of cultural exchange in history; for example in literary works transmitted through intermediary means or perhaps in those minute details expressed in art, architecture, liturgy etc., which he collectively calls 'Syrian' influences in Ethiopia; cf. Witold Witakowski, "Syrian Influences in Ethiopia," in EAe 4 (2010): 781. I also intend to place forward a similar approach here while focusing on the idea of a 'Syrian' background of the Nine Saints as a collective consciousness based on their contributions in Ethiopia, either direct or indirect, while simultaneously also not ignoring the scientific aspects of the problem involved.

$30 \quad J a c o p o$ Gnisci and Antonella Brita, "Hagiography in Ge'ez," in Treasures of Ethiopia and Eritrea in the Bodleian Library, Oxford, ed. Jacopo Gnisci (Oxford: Manar al-Athar, University of Oxford, 2019), $5^{8 .}$ 
The life of a saint was usually written by a monk from the saint's own monastery, who sought by writing the work to glorify the saint as well as his monastery. His goal was not to write history in any modern critical sense of that word, and thus the political, social, and historical data which are of such interest to us are accidental by-products. He weighed his sources (if at all) not to produce the most accurate version, but rather to produce a work which suited his purposes. ${ }^{31}$

Accordingly, on account of the fact that the primary purpose of these works of literature was positioned at the exaltation of saints, they were able to adopt any literary form relevant to the context in order to appeal to the local community without paying keen attention to its historic details and consequently ended up to be, to a large extent, or perhaps even totally disconnected from actual facts. ${ }^{32}$ "Because of the sensitivity of hagiographic literature to the surrounding society texts were shaped both in their initial writing and throughout the course of transmission by the needs and concerns of the religious community as perceived by hagiographers and scribes." ${ }^{33}$ This is the reason that when a situation occurs where the hagiographers were left with an inadequate amount of sources, they equitably complemented their accounts by inserting narratives and figures taken from the Bible or other prevalent Christian literature as well as from some popular and conventional hagiographic writings, such as the Life of St. Anthony. ${ }^{34}$ As a consequence:

[...] while specialists in Ethiopian literature and history have long realized the potential value of these gädlat as sources for the study of Ethiopian history, the tendency towards idealization displayed in these works, as well as their abundant miracles and anachronisms, have left historians uncertain as to how to extract reliable information from them. ${ }^{35}$

As Taddesse Tamrat points out:

[...] the authors of the gädls placed their saintly heroes within certain historical contexts, sometimes imaginary, but mostly within the context

31 Steven Kaplan, "Hagiographies and the History of Medieval Ethiopia," History in Africa 8 (1981): 110-111.

32 Hippolyte Delehaye, The Legends of the Saints: An Introduction to Hagiography, trans. Virginia Mary Crawford (London: Longmans, Green, and Company, 1907), 3.

33 Kaplan, "Hagiographies," 114.

34 Ibid., 111.

35 Ibid., 107. 
of the period in which they actually lived. Here our problem is no longer the alteration of the period in which the hero lived. ${ }^{36}$

Hence, in the analysis with hagiographies, that which matters profoundly as a problem should be the attempts to understand the motives or the causes that had influenced the author (or the scribe) in the depiction of events rather than lingering on the actuality of the events portrayed.

Considering the hagiographies of the Nine Saints, the tales are preserved in the form of nine gädlat or perhaps ten, largely focusing on their miracle accounts and mostly composed in the style of a sermon intended to be read to the faithful on the day of commemoration of these saints. Antonella Brita clarifies that the relation between the homiletic and the narration is not always constant and depends as much on the function that the author intended to convey to his story on the availability of information about the protagonist. ${ }^{37}$ Moreover, there exists already a historical time gap of approximately around a thousand years between these writings and the events described, a reason for which one can certainly not deny the possibilities of cultural influences intersecting the historical data giving rise to the following conceivable options, i.e. the events as described in the writings were factual and transmitted as oral traditions passing through different cultural backgrounds before finally being written down; or, "some of these texts attested in the manuscripts must have circulated much earlier than the 13th century"38 and unfortunately did not survive or were eventually lost; or the events and the data as such are only later interpretations developed by the hagiographers inspired from other existing writings of their contemporary or previous times. Modern scholars like Paolo Marrassini are mostly of the third opinion that they were "all inspired by writings translated in the preceding decades" 39 and viewed the collection of the gädlat noteworthy only as "a general testimony."40

Nevertheless, it would certainly be too harsh if one attempted to reduce the significance of these pieces of literature to mere fiction since "fiction presupposes conscious creative action. In a certain sense, there was no conscious fictional manipulation of history in early hagiographic literature, but a deliberate

36 Taddesse Tamrat, "Hagiographies and the Reconstruction of Medieval Ethiopian History," Rural Africana 11 (1970): 15 .

37 Brita, I Racconti, 55; Brita, "Nine Saints," 1190.

38 Brita, "Hagiography," 230.

39 Marrassini, “Una Chiesa Africana," 203; Munro-Hay, "Saintly Shadows," 142.

40 Marrassini, "Una Chiesa Africana," 197. 
transformation of biographical reconstructions into hagiographic images." ${ }^{41}$ Also, it would be serious neglect in the study if one did not pay ample attention to the factors that had influenced the works of the hagiographers or the scribes because, "while aesthetic and didactic concerns were of some significance, issues of monastic and political prestige seem to have exerted the strongest influence on their work." 42

For instance, the sequence of missionary activities of the Nine Saints and the traditional attribution to their Syrian provenance is in close proximity to the narration of accounts relating to the 'Thirteen Syrian Ascetic fathers' identified in the Georgian tradition dating back to the sixth century, ${ }^{43}$ implying also a possibility of the presence and influence of common cultural memories about Syrian monks that might have been shared and transferred between Christian communities having similar monastic traditions since "the pattern of Syrian missionary ascetics is similar over the vast religious and cultural realm of the Late Antique Mediterranean." 44

Moreover, one shall also not neglect the fact that these hagiographical texts would convey their underlying political aspects too since these texts often reflected the layers of native resistance towards the primacy of the Alexandrian (Coptic) Patriarchate over Ethiopia ${ }^{45}$ because of which it is conceivable to speculate that the Ethiopians might have wanted to emphasize on nonEgyptian monastic roots. Rochus Zuurmond, the Biblical scholar, while still acknowledging the Syrian provenance of the saints by stating that "there may always have been monks with a Syrian background, either from Syria or from Egypt, who occasionally corrected Gəəəz text or suggested such corrections to the Ethiopian scribes, in- or outside Ethiopia," ${ }^{46}$ also puts forward his speculation whether the narratives might actually reflect the political context of antagonism between Egypt and Ethiopia during the thirteenth century instead of a fifth-century ecclesiastical history since the opposition to Alexandria in Ethiopia was also buoyed by the patriarch of Antioch at that time. ${ }^{47}$

41 Giovavanni Paolo Maggioni, "Texts between History and Fiction in Medieval Hagiography," in Fiction and Figuration in High and Late Medieval Literature, ed. Marianne Pade et al. (Roma: Edizioni Quasar, 2016), 75.

42 Kaplan, "Hagiographies," 114.

43 Shota Matitashvili, "The Monasteries Founded by the Thirteen Syrian Fathers in Iberia: The Rise of Monasticism in Sixth-Century Georgia," Studies in Late Antiquity 2, no. 1 (2018): 4-39. Brita, I racconti, 8-17.

44 Ibid., 11.

45 Stuart C. Munro-Hay, Ethiopia and Alexandria: The Metropolitan Episcopacy of Ethiopia (Warszawa: Zaś Pan, 1997).

46 Rochus Zuurmond, ed., Novum Testamentum Aethiopice: The Synoptic Gospels. Part I: General Introduction (Stuttgart: F. Steiner Verlag Wiesbaden, 1989), 117. 
Thus, even minor narratives concerning the tradition of the Nine Saints that might be considered as 'least significant' in terms of a historical document would certainly incorporate the potential of delivering some substantial insight into the religious, cultural and, socio-political situations of the time surrounding the composition and later developments of these accounts. Therefore, any inferences on the credibility of a hagiographic text as a historical source can be drawn out only through a process of methodical analyses as well as comparisons with other texts in order to carefully examine its process of developments through the various socio-political elements of cultural memory in history.

\subsection{Early Ethiopian Monastic Units as Figures of Memory: Syrian or Egyptian?}

Even when the linguistic analyses fail to substantiate the postulations of the Syrian connection, the accounts of the Nine Saints can still be further analysed to study whether or not they reflect any traces of Syrian elements in ascetic practices, a topic that rather demands a more vicarious approach than an absolute empirical investigation. Although we now lack proper documentation about the beginnings and development of monastic life in Ethiopia, ${ }^{48}$ the introductory models of ascetic practices that include both the anchoritic style (for instance, as practised by $A b b a$ Pänțälewon) as well as the well-organized cenobitic style (for example, the Däbrä Dammo monastery that directly relates to Abba Zämika'el Arägawi) are traditionally understood to have been carried to Ethiopia towards the end of the $5^{\text {th }}$ century with the advent of the Nine Saints. ${ }^{49}$

Moreover, even when the conclusions of the linguistic and philological studies held by scholars such as Polotsky and Marrassini, in their respective

48 Gianfrancesco Lusini, "The Ancient and Medieval History of Eritrean and Ethiopian Monasticism: An Outline," in A Companion to Medieval Ethiopia and Eritrea, ed. Samantha Kelly (Leiden: Brill, 2020), 196.

49 The places where the saints are believed to have established their monasteries as per the information from their respective hagiographies are: Yəḥa ( $A b b a$ Afșe), Däbrä Halleluya ( $A b b a$ Alef), Däbrä Mädära ( $A b b a$ Gärima or Yəsḥaq), an unidentified place in the Baraka desert ( $A b b a$ Guba), Däbrä Qwänașəl in 'Adwa ( $A b b a$ Liqanos), Däbrä Pänțälewon in Aksum (Abba Pänțälewon), Șädäya (Abba Șəḥma), Gər'alta (Abba Yəm’ata), Däbrä Dammo (Abba Zämikael Arägawi). The saints are believed to have established their own monasteries in those places where they settled, particularly surrounding Aksum, where now churches exist (although not monastic communities) close to the ancient ruins at various sites connected to these saints. Steven Kaplan, "Monasticism," in EAe 5 (2014): 444; Steven Kaplan, "Monasteries," in EAe 3 (2007): 988. 
works, ${ }^{50}$ more likely point towards the Egyptian origins of the monks, it has, however, to be noted that the purported ascription of monastic origins to Egypt is apparently due to the massive influence of Egyptian monasticism to the extent that the "later Syrian monks were prepared to forget their genuinely native heritage" 51 and therefore simultaneously "it can be admitted that the same Egyptian monasticism played a mediating role in transmitting to Ethiopia elements of the asceticism practised in the deserts of Syria and Palestine since the end of the third century."52

A stark observation on the monastic features of their time period might present to us reflections of certain distinct Syrian elements. This is because the expressions of the monastic practices or discipline contrasted between Egypt and Syria at certain levels particularly among the anchorites, as the anchoritic roots and observances in Syria emerged as a relatively more rigorous and idiosyncratic lifestyle of its times ${ }^{53}$ which is why when "[...] Egypt's forte was cenobitic monasticism, in Syria it was the solitary virtuoso who dominated the scene." ${ }^{54}$

The severity in the eremitic practices of Syrian ascetics could possibly be due to the differences in the landscapes and the climatic conditions of the two regions since Syria had better and more favourable geographic conditions with an extensive terrain of steppe regions, mountains and deserts in contrast to the grating desert atmosphere in Egypt forcing the Egyptian anchorites to be confined within their monastic cells; ${ }^{55}$ as a result of which "the human contrast between the man in the desert and the man in the world was heightened"56 among the Syrian eremites. ${ }^{57}$

50 Polotsky, "Aramaic, Syriac, and Ge'ez"; Marrassini, "Once Again on the Question of Syriac Influences"; Marrassini, "Some Considerations."

$5^{1} \quad$ Sebastian P. Brock, "Early Syrian Asceticism," Numen 20, no. 1 (1973): 3.

52 Lusini, "The Ancient and Medieval History," 196, fn. 10.

53 Jeffrey Conrad, "Egyptian and Syrian Asceticism in Late Antiquity," Syriac Studies, 16 September 2015, URL: https://syriacstudies.com/2015/o9/16/egyptian-and-syrian-asceticism -in-late-antiquity-jeffrey-conrad-2/.

54 Brock, "Early Syrian Asceticism," 13.

55 Conrad, "Egyptian and Syrian Asceticism"; Peter Brown, "The Rise and Function of the Holy Man in Late Antiquity," Journal of Roman Studies 61 (1971): 83-84.

$56 \quad$ Ibid., 83 .

57 Although the anchorites of Egypt went in pursuit of harsh deserts, the Egyptian cenobites nevertheless also instituted monasteries within the inhabited regions such as fertile gorges, riverbanks, villages, and towns. Cf. James E. Goehring, "Withdrawing from the Desert: Pachomius and the Development of Village Monasticism in Upper Egypt," The Harvard Theological Review 89, no. 3 (1996): 268. However, the contrast we analyse here is primarily between the eremites of Egypt and Syria. 
However, the heightened contrast did not isolate the hermits of Syria far away from the villagers ${ }^{58}$ unlike the Egyptian eremites who rather preferred to detach themselves from the populated world and settle in modified cells rebuilt upon those sites which were considered as the fringes of their society such as the ancient temple ruins, pharaonic monuments, tombs and natural caves. ${ }^{59}$ The eremitic style of asceticism in Syrian terrains rather undertook a visible form as the hermits in fact got engaged with their societies acting as counsellors, instructors and mediators. ${ }^{60}$ Perhaps the most acclaimed and well documented among these ascetic practitioners were the 'pillar-saints' or the 'stylites' who practised their monastic disciplines by dwelling on top of pillars or high columns; Saint Simeon Stylites (ca. 389-459) being the prime among them. ${ }^{61}$

If we now try to study these distinguishing features of the Syrian anchoritic model in relation to the Ethiopian ascetic practices and the tradition of the Nine Saints, we can see, according to the hagiographic accounts, that some of the Nine Saints like $A b b a$ Liqanos, Abba Afșe and Abba Pänțälewon for certain practised the hermitic style of asceticism, ${ }^{62}$ and a closer observation on their mode of eremitic practices would reflect us entangled layers of what we distinguished earlier as Syrian elements. Further, almost all of the terrestrial

$5^{8}$ Jakob Ashkenazi, "Holy Man versus Monk—Village and Monastery in the Late Antique Levant: Between Hagiography and Archaeology," Journal of the Economic and Social History of the Orient 57 , no. 5 (2014): 745-765.

59 Darlene L. Brooks Hedstrom, "The Geography of the Monastic Cell in Early Egyptian Monastic Literature," Church History 78, no. 4 (2009): 756-791.

6o "[...] the hermit deliberately placed himself on the mountain tops; [...] from such tops, he could look down on prosperous villages and on the farmers working on the slopes. He belonged to a world that was not so much antithetical to village life as marginal. He was known to the hunter: he too was on the mountainside 'to stalk his god." Brown, "The Rise and Function of the Holy Man," 83-84.

61 The fame and practice of this innovative monastic trend of stylitism spread beyond the geographical borders of Syria to several other surrounding regions like Palestine, Arabia, Mesopotamia, Egypt, Georgia, Paphlagonia, Cilicia, Phoenicia, Osrhoene etc. For further reading on the Stylites, see: Emma Loosley Leeming, Architecture and Asceticism: Cultural Interaction between Syria and Georgia in Late Antiquity (Leiden: Brill, 2018), 85-102. Also see: David T.M. Frankfurter, "Stylites and Phallobates: Pillar Religions in Late Antique Syria," Vigiliae Christianae 44, no. 2 (1990): 168-198; Herbert Thurston, "Stylites or PillarSaints," Studies: An Irish Quarterly Review 12, no. 48 (1923): 584-596; Brock, "Early Syrian Asceticism."

62 Cf. Brita, I Racconti. Meanwhile, we can also see the other model among saints like Abba Arägawi who is directly linked in his vitae to the Egyptian monastic tradition as the disciple of Pachomius and is accredited with the founding of Däbrä Dammo, one of Ethiopia's greatly celebrated ancient monasteries of the cenobitic style. 
landscapes chosen by the saints for their monastic settlements were of the same fashion, i.e. to settle at a relatively higher place than the cities or villages which were mostly either a hill or a mountain while at the same time not totally detached from the inhabited region below. ${ }^{63}$

The monasteries of $A b b a$ Päntälewon and $A b b a$ Liqanos resemble the archaeological phenomena of Syrian eremitic units especially of the pillar-saints, with the hill or the high terrain serving as "an analogue to the pillar"64 and hence "were vertically distanced from the city, yet could be seen from all around the immediate landscape: they are at once isolated yet central." ${ }^{65}$ Also, the propinquity of both these saints to the political affairs of the state is somewhat evident from their involvement in the ascension of Emperor Tazena ${ }^{66}$ as well as from the cordial relationship between King Kaleb and Pänțälewon as mentioned in the hagiographies where the monk plays the role of a spiritual counsellor to the King during warfare. ${ }^{67}$ The choice of unique and high landscapes, as well as the involvement of the monks in social life, are some unusual characteristics belonging to the Syrian hermits ${ }^{68}$ giving rise to the possible implication that "although possessing Greek names, Pänțälewon and Liqanos could actually be hermits in the Syriac tradition." ${ }^{69}$

The other saints like Abba Yəm’ata, Abba Arägawi, Abba Alef and Abba Gärima also preferred to settle at relatively higher terrains or mountains ${ }^{70}$ where either churches or monastic units still exist; whereas the sites of monasteries established by the remaining saints are rather indistinct and, according

63 Niall Finneran, "Ethiopian Christian Material Culture: The International Context. Aksum, the Mediterranean and the Syriac Worlds in the Fifth to Seventh Centuries," in Incipient Globalization? Long-Distance Contacts in the Sixth Century, ed. Anthea Harris (Oxford: Archaeopress, 2007), 85. Two of those sites which I could visit during my travel to Ethiopia in September 2019 were the $A b b a$ Pänțälewon monastery and the Abuna Yəm’ata Guh; the former situated atop a small hill, hardly few miles away from the town centre in Aksum and the later a rock-hewn church dedicated in honour of Saint Yəm'ata situated atop the Gər'alta mountains of the Tigray region at a stupendous height of approximately 864 o feet from sea level.

64 Ibid.

65 Niall Finneran, "Hermits, Saints, and Snakes: The Archaeology of the Early Ethiopian Monastery in Wider Context," The International Journal of African Historical Studies 45, no. 2 (2012): 26 o.

66 Sergew Hable Sellassie, Ancient and Medieval Ethiopian History, 116-117.

67 Budge, The Book of the Saints. Vol. 1/2, 117; Balthazar Telles, The Travels of the Jesuits in Ethiopia, trans. John Stevens (London: J. Knapton, 1710), 93-94.

68 Brown, "The Rise and Function of the Holy Man."

69 Finneran, "Ethiopian Christian Material Culture," 85.

70 However, the choice of location for their monastic settlements at high regions could also be merely a strategic attempt to protect themselves from their enemies. 
to the archaeologist Niall Finneran, in almost all of the monastic units of the Nine Saints, "the Syrian cultural tradition does appear, from at least a landscape perspective, to run strongly in the story of early Ethiopian monasticism."71 Thus, when analysing the archaeological landscapes of these monasteries, the existing gap between the shreds of textual evidence and the material cultural elements observed in the monastic units lead us to develop a rather imaginative and empathetic approach towards Syrian influences; whereas their connection to the available historical material remains very slim.

\section{4}

\section{Conclusion}

There is no denying that the theory of the 'Syrian origin' of the Nine Saints in all can be evaluated only as a contingent proposition that emerged from a series of misinterpretations put together by a collegium of western scholars. Yet, the currently available textual and linguistic evidence can neither completely prove nor disprove the problem of Syrian provenance but can only derive a solution as either more likely or less likely, which in this case seems only to be less likely if we do not consider the notion of 'ultimate origin' into our discussions. But does the concept of 'ultimate origin' matter to our current topic? To a large extent what matters profoundly concerning our research problem is rather the inquiry of 'direct origin' than the question of 'ultimate origin.' Even so, the question of 'ultimate origin', (if at all it matters to the context) can be taken into consideration while dealing with the idea of 'Syrianness' of the Nine Saints as a phenomenon of 'cultural memory' which in turn demands appreciation and empathy towards the 'figures of memory' that sustain the tradition. Accordingly, the figures of memory that were discussed in this paper, the hagiographies and the monastic units reflect to an extent a few Syrian correlations within their material cultural aspects as well as in their underlying socio-political motives.

Therefore, while considering the problem of 'Syrian origin' of the Nine Saints a possible speculation could turn out that, despite the dissonance in the existing arrays of evidence, the chances of underscoring a conjunction with Syrian elements could still appear feasible, if not by direct at least by means of indirect contacts that could have happened through other mediatory carriers like Egypt or Arabia. However, such an approach encompasses hidden snares of presenting the problem in a reductive manner and hence does not serve as an outright

$71 \quad$ Finneran, "Hermits, Saints, and Snakes," 261. 
solution but only as a conjecture, for which reason one must be simultaneously aware of the scientific discrepancies involved within the subject matter to demystify facts from mere typological allusions.

\section{List of References}

Ashkenazi, Jakob. "Holy Man versus Monk-Village and Monastery in the Late Antique Levant: Between Hagiography and Archaeology." Journal of the Economic and Social History of the Orient 57 , no. 5 (2014): 745-765.

Assmann, Jan, and John Czaplicka. "Collective Memory and Cultural Identity." New German Critique 65 (1995): 125-133.

Brita, Antonella. "Hagiography and Monasticism in the Ethiopian Church." In Ethiopia: History, Culture and Challenges, edited by Siegbert Uhlig, David L. Appleyard, Alessandro Bausi, Wolfgang Hahn, and Steven L. Kaplan, 230-233. Münster: Lit, 2017.

Brita, Antonella. I racconti tradizionali sulla Seconda Cristianizzazione dell'Etiopia: Il ciclo agiografico dei Novi Santi. Napoli: Università degli studi di Napoli l'Orientale, 2010.

Brita, Antonella. "Nine Saints." In EAe 3 (2007): 1188-1191.

Brock, Sebastian P. "Early Syrian Asceticism." Numen 20, no. 1 (1973): 1-19.

Brooks Hedstrom, Darlene L. "The Geography of the Monastic Cell in Early Egyptian Monastic Literature." Church History 78, no. 4 (2009): 756-791.

Brown, Peter. "The Rise and Function of the Holy Man in Late Antiquity." Journal of Roman Studies 61 (1971): 80-101.

Budge, Ernest A. Wallis. The Book of the Saints of the Ethiopian Church. Vol. 1/2. Hildesheim: Georg Olms Verlag, 1976.

Budge, Ernest A. Wallis. The Book of the Saints of the Ethiopian Church. Vol. 3/4. Hildesheim: Georg Olms Verlag, 1976.

Conrad, Jeffrey. "Egyptian and Syrian Asceticism in Late Antiquity." Syriac Studies, 16 September 2015, URL: https://syriacstudies.com/2015/o9/16/egyptian-and-syrian -asceticism-in-late-antiquity-jeffrey-conrad-2/.

Conti Rossini, Carlo. “La Leggenda di Abbā Afșē in Etiopia." In Mélanges Syriens offerts à Monsieur René Dussaud. Vol 1, 151-156. Paris: Librairie orientaliste Paul Geuthner, 1939 .

Conti Rossini, Carlo. "L'Omilia di Yohannes, Vescovo d'Aksum, in Onore di Garimâ." In Actes du XIe Congrès International des Orientalistes. Paris. 1897. Vol. 4, 139-177. Paris: Impr. nationale, 1898.

Conti Rossini, Carlo. Storia d'Etiopia. Bergamo: Istituto Italiano d'Arte Grafiche, 1928.

Conti Rossini, Carlo. Vitae Sanctorum Antiquiorum. Vol. 1: Acta Yāred et Panțalewon. Leuven: Durbecq, 1955 . 
David T.M. Frankfurter. "Stylites and Phallobates: Pillar Religions in Late Antique Syria." Vigiliae Christianae 44, no. 2 (1990): 168-198.

Delehaye, Hippolyte. The Legends of the Saints: An Introduction to Hagiography, translated by Virginia Mary Crawford. London: Longmans, Green, and Company, 1907.

Fiaccadori, Gianfranco. "Between Arabia and Ethiopia." In Life and Works of Saint Gregentios, Archbishop of Taphar: Introduction, Critical Edition and Translation, edited by Albrecht Berger, 58-72. Berlin: Walter de Gruyter, 2006.

Finneran, Niall. "Ethiopian Christian Material Culture: The International Context. Aksum, the Mediterranean and the Syriac Worlds in the Fifth to Seventh Centuries." In Incipient Globalization? Long-Distance Contacts in the Sixth Century, edited by Anthea Harris, 75-89. Oxford: Archaeopress, 2007.

Finneran, Niall. "Hermits, Saints, and Snakes: The Archaeology of the Early Ethiopian Monastery in Wider Context." The International Journal of African Historical Studies 45, no. 2 (2012): 247-271.

Gnisci, Jacopo, and Antonella Brita. "Hagiography in Ge'ez." In Treasures of Ethiopia and Eritrea in the Bodleian Library, Oxford, edited by Jacopo Gnisci, 58-69. Oxford: Manar al-Athar, University of Oxford, 2019.

Goehring, James E. "Withdrawing from the Desert: Pachomius and the Development of Village Monasticism in Upper Egypt." The Harvard Theological Review 89, no. 3 (1996): 267-285.

Guidi, Ignazio. “Il ‘Gadla Aragâwî'.” In Atti della R. Accademia dei Lincei, Classe di Scienze Morali, Storiche e Filologiche. Vol. 2, 54-96. Roma: Tipografia della R. Accademia dei Lincei, 1896.

Guidi, Ignazio. Le Traduzioni degli Evangeli in Arabo e in Etiopico. Roma: Salviucci, 1888.

Guidi, Ignazio. Storia della Letterature Etiopica. Rome: Istituto per l'Oriente, 1932.

Hagos Abrha. "Philological Analysis of the Manuscripts of Gädlä Yəm‘ata." Ityopis 1 (2011): 61-75.

Halbwachs, Maurice. On Collective Memory, translated and edited by Lewis A. Coser. Chicago: University of Chicago Press, 1992.

Kammerer, Albert. Essai sur l'histoire antique d'Abyssinie. Le royaume d'Aksum et ses voisins d'Arabie et de Meroe. Paris: Geuthner, 1926.

Kany, Roland. Mnemosyne als Programm. Geschichte, Erinnerung und die Andacht zum Unbedeutenden im Werk von Usener, Warburg und Benjamin. Tübingen: Niemeyer, 1987.

Kaplan, Steven. "Hagiographies and the History of Medieval Ethiopia." History in Africa 8 (1981): 107-123.

Kaplan, Steven. "Monasteries." In EAe 3 (2007): 987-993.

Kaplan, Steven. "Monasticism." In EAe 5 (2014): 443-447.

Leeming, Emma Loosley. Architecture and Asceticism: Cultural Interaction between Syria and Georgia in Late Antiquity. Leiden: Brill, 2018. 
Leslau, Wolf. Comparative Dictionary of Ge'ez (ClassicalEthiopic): Ge'ez-English, EnglishGe'ez, with an Index of the Semitic Roots. Wiesbaden: Harrassowitz, 1987.

Lusini, Gianfrancesco. "The Ancient and Medieval History of Eritrean and Ethiopian Monasticism: An Outline." In A Companion to Medieval Ethiopia and Eritrea, edited by Samantha Kelly, 194-216. Leiden: Brill, 2020.

Maggioni, Giovavanni Paolo. "Texts between History and Fiction in Medieval Hagiography." In Fiction and Figuration in High and Late Medieval Literature, edited by Marianne Pade, Anders Cullhed, Anders Hallengren, and Brian Møller Jensen, 75-81. Roma: Edizioni Quasar, 2016.

Marrassini, Paolo. "Frustula Nagranitica." Aethiopica 14, no. 1 (2011): 7-32.

Marrassini, Paolo. "Once Again on the Question of Syriac Influences in the Aksumite Period." In Languages and Cultures of Eastern Christianity: Ethiopian, edited by Alessandro Bausi, 209-219. Farnham: Ashgate, 2012.

Marrassini, Paolo. “Some Considerations on the Problem of the 'Syriac Influences' on Aksumite Ethiopia." Journal of Ethiopian Studies 23 (1990): 35-46.

Marrassini, Paolo. Storia e leggenda dell'Etiopia tardoantica. Le iscrizioni reali aksumite con un'appendice di Rodolfo Fattovich su La civiltà a ksumita: aspetti archeologici e una nota editoriale di Alessandro Bausi. Brescia: Paideia, 2014.

Marrassini, Paolo. "Una Chiesa Africana. L'Etiopia fra Antiochia e Alessandria." In XXVIII Corso di Cultura sull'Arte Ravennate e Bizantina, 193-203. Ravenna: Edizioni del Girasole, 1981.

Matitashvili, Shota. "The Monasteries Founded by the Thirteen Syrian Fathers in Iberia: The Rise of Monasticism in Sixth-Century Georgia." Studies in Late Antiquity 2, no. 1 (2018): 4-39.

Michael, Belaynesh, S. Chojnacki, and Richard Pankhurst. The Dictionary of Ethiopian Biography: From Early Times to the End of the Zagwé Dynasty c. 1270 A.D. Vol. 1. Addis Ababa: Institute of Ethiopian Studies, 1975.

Munro-Hay, Stuart C. Ethiopia and Alexandria: The Metropolitan Episcopacy of Ethiopia. Warszawa: Zaś Pan, 1997.

Munro-Hay, Stuart C. "Saintly Shadows." In Afrikas Horn: Akten der Ersten Internationalen Littmann-Konferenz, 2. bis 5. Mai 2002 in München, edited by Walter Raunig and Steffen Wenig, 137-168. Wiesbaden: Harrassowitz, 2005.

Oudenrijn, Marcus Antonius van den. La vie de saint Za Mīkāêl 'Aragāwī. Fribourg: Imprimere St.-Paul, 1939 .

Polotsky, Hans Jakob. “Aramaic, Syriac, and Ge'ez." Journal of Semitic Studies 9 (1964): 1-10.

Sergew Hable Sellassie. Ancient and Medieval Ethiopian History to 1270. Addis Ababa: United Printers, 1972.

Taddesse Tamrat. "Hagiographies and the Reconstruction of Medieval Ethiopian History." Rural Africana 11 (1970): 12-20. 
Telles, Balthazar. The Travels of the Jesuits in Ethiopia, translated by John Stevens. London: J. Knapton, 1710.

Thurston, Herbert. "Stylites or Pillar-Saints." Studies: An Irish Quarterly Review 12, no. 48 (1923): 584-596.

Ullendorff, Edward. Ethiopia and the Bible. London: Oxford University Press, 1968.

Vööbus, Arthur. Early Versions of the New Testament: Manuscript Studies. Stockholm: Estonian Theological Society in Exile, 1954.

Vööbus, Arthur. History of Asceticism in the Syrian Orient: A Contribution to the History of Culture in the Near East. Vol. 3. Louvain: Secrétariat du Corpus sco, 1958.

Westcott, Brooke Foss, and Fenton John Anthony Hort. The New Testament in the Original Greek. Cambridge: Macmillan and Co., 1882.

Witakowski, Witold. "Syrian Influences in Ethiopia." In EAe 4 (2010): 782-784.

Witakowski, Witold. "Syrian Influences in Ethiopian Culture." In Languages and Cultures of Eastern Christianity: Ethiopia, edited by Alessandro Bausi, 197-208. Farnham: Ashgate, 2012.

Yaqob Beyene, ed. and trans. Giyorgis di Saglā: Il Libro del Mistero (Mașhafa Mesțir). Parte Prima. Louvain: Peeters, 1990.

Zuurmond, Rochus, ed. Novum Testamentum Aethiopice: The Synoptic Gospels. Part I: General Introduction. Part II: Edition of the Gospel of Mark. Stuttgart: F. Steiner Verlag Wiesbaden, 1989 . 